\title{
Neurotoxoplasmosis in a Patient with Acquired Immunodeficiency Syndrome: Magnetic Resonance and Magnetic Resonance Spectroscopy Findings
}

\author{
Edinsel İmmün Yetersizlik Sendromlu Hastada Nörotoksoplazmozis: Manyetik \\ Rezonans ve Manyetik Rezonans Spektroskopi Bulguları
}

\author{
(1) Pınar Gülmez Çakmak¹, (D) Selda Sayın Kutlu² \\ 1Pamukkale University Faculty of Medicine, Department of Radiology, Denizli, Turkey \\ 2Pamukkale University Faculty of Medicine, Department of Infectious Diseases and Clinical Microbiology, Denizli, Turkey
}

\begin{abstract}
Human immunodeficiency virus (HIV) infection and acquired immunodeficiency syndrome (AIDS) is an important public health problem. In recent years, opportunistic infections that can develop in patients with AIDS are rapidly diagnosed by imaging modalities. A 31-year-old HIV-positive male patient presented with fever, headache and progressive bilateral muscle weakness. Magnetic resonance imaging (MRI) revealed multiple mass lesions with peripheral edema. In MR spectroscopy (S), lactate-lipid peak was detected. Hemorrhagic transformation was observed in some lesions in control brain MRI. Here, we aimed to present MRI and MRS findings of a patient with neurotoxoplasmosis and to demonstrate that hemorrhagic transformation may develop during follow-up and treatment.
\end{abstract}

Keywords: AIDS, cerebral toxoplasmosis, HIV, magnetic resonance spectroscopy
ÖZ

İnsan immün yetmezlik virüsü (HIV) enfeksiyonu ve edinsel immün yetmezlik sendromu (AIDS) önemli bir halk sağlığı sorunudur. Son yıllarda, edinsel immün yetersizlik sendromlu hastalarda gelişebilen fırsatçı enfeksiyonlar, görüntüleme ile hızlı bir şekilde tanı almaktadır. Otuz bir yaşında bir HiV-pozitif hasta; ateș, baș ağrısı ve ilerleyen iki taraflı kas güçsüzlüğü ile başvurdu. Manyetik rezonans görüntülemede (MRG) ödemi de bulunan çok sayıda kitle lezyonu izlendi. Lezyonların MR spektroskopisinde (S), laktat ve lipit piki tespit edildi. Kontrol beyin MRG'de bazı lezyonlarda hemorajik transformasyon gözlendi. Bu yazıda, bir nörotoksoplazmozis hastasının MR ve MRS görüntüleme bulgularını sunmak ve takip-tedavi sırasında hemorajik transformasyonun gelişebileceğini göstermek istedik.

Anahtar Kelimeler: AIDS, serebral toksoplazmozis, HIV, manyetik rezonans spektroskopi

\section{Introduction}

Toxoplasma gondii is an intracellular protozoan that causes central nervous system involvement in patients with human immunodeficiency virus (HIV) infection or acquired immunodeficiency syndrome (AIDS). Toxoplasma is transmitted by oral or transplacental route (1). Acute infection is usually asymptomatic. Neurotoxoplasmosis is caused by the reactivation of latent infection in the brains of immunocompromised patients with a CD4+ T lymphocyte count of less than 200 cells/ $\mu \mathrm{L}(2,3)$. The clinical presentation most commonly includes headache, fever, hemiparesis, intracranial mass, and cranial nerve palsy (4). In addition to the brain, lung, heart and skeletal muscle involvement can be seen. Today, early diagnosis of HIV infection and opportunistic infection prophylaxis in patients with AIDS has reduced the frequency of neurotoxoplasmosis.
We present magnetic resonance imaging (MRI) and MR spectroscopy (S) findings of a patient with neurotoxoplasmosis.

\section{Case Report}

A 31-year-old male patient admitted to emergency department of our hospital in December 2017 with complaints of fever, headache, vomiting, blurred vision and progressive bilateral weakness. Regarding medical history and laboratory findings of the patient, AIDS was diagnosed in the emergency department. Laboratory data showed reactive HIV antibodies and HIV-RNA was 1.109 .000 copies/mL. An absolute CD4 count was 8 cells/ $\mathrm{mm}^{3}$. Brain MRI was performed at 1.5 Tesla (Signa Excite HD; GE Medical Systems, Milwaukee, WI, USA) with an 8-channel head coil due to fever and neurological symptoms. MRI showed T2-FLAIR hyperintense lesions

(c) Copyright 2019 by the Istanbul Training and Research Hospital/istanbul Medical Journal published by Galenos Publishing House. 
with edema in the centrum semiovale, basal ganglia, corticomedullary junction and cerebellum (Figure 1). In addition, a ring-enhancing lesion in the cerebellum was also observed in contrast-enhanced MRI (Figure 2). MRS (single voxel, short TE) was performed for the cerebellar

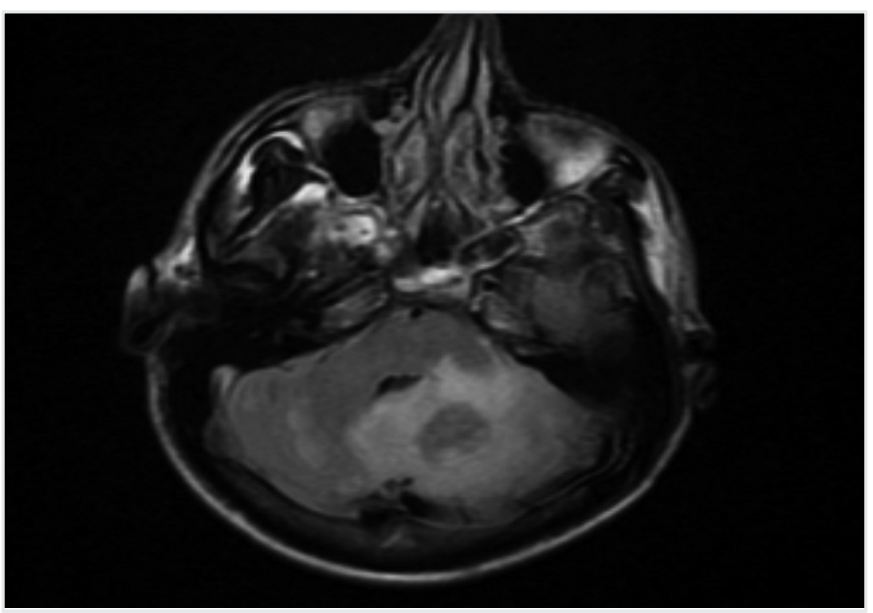

Figure 1a. Axial T2-FLAIR images showing hyperintense lesions with edema in the cerebellum

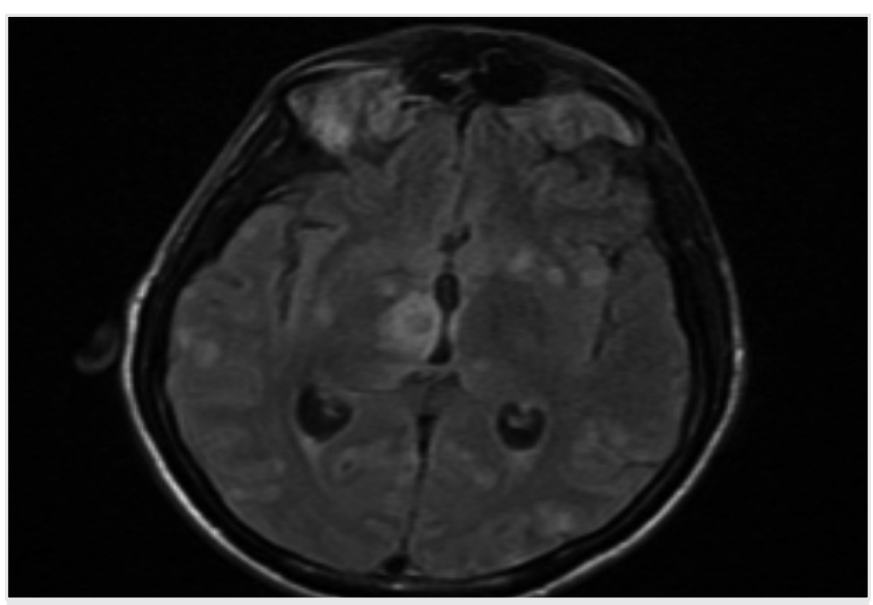

Figure 1b. Axial T2-FLAIR images showing hyperintense lesions with edema in the basal ganglia

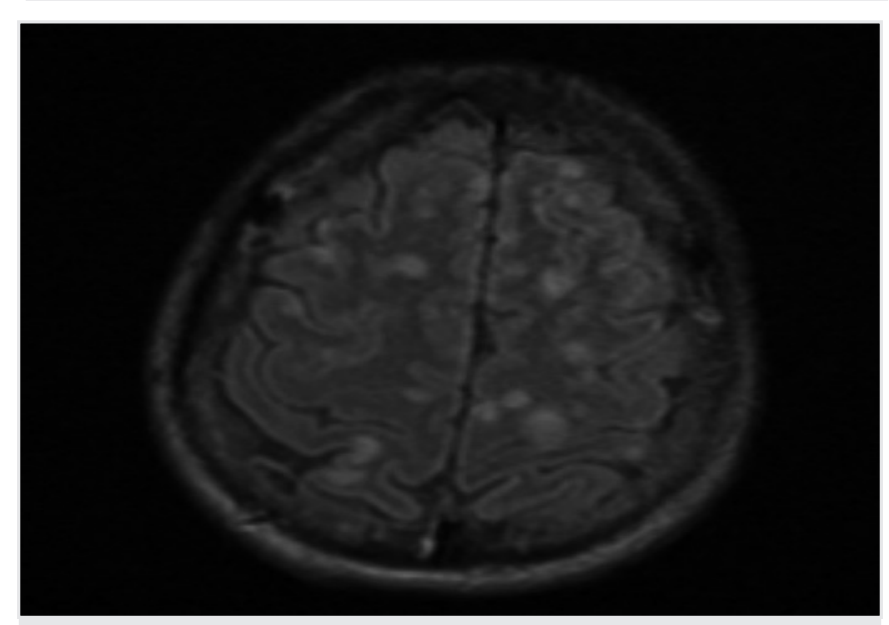

Figure 1c. Axial T2-FLAIR images showing hyperintense lesions with edema at the corticomedullary junction and in the centrum semiovale lesion. Point resolved spectroscopy sequence (PRESS) with short echo time was used. PRESS parameters were TR/TE=2000/32 ms; NEX=128 and voxel volume $=1 \mathrm{~mL}$. MRS revealed Choline (Cho) reduction at 3.19 ppm, creatinine reduction at $3.04 \mathrm{ppm}$ and $\mathrm{N}$-acetylaspartate (NAA) reduction at $2.00 \mathrm{ppm}$, and increased lipid-lactate (Lip/Lac) at $1.33 \mathrm{ppm}$.

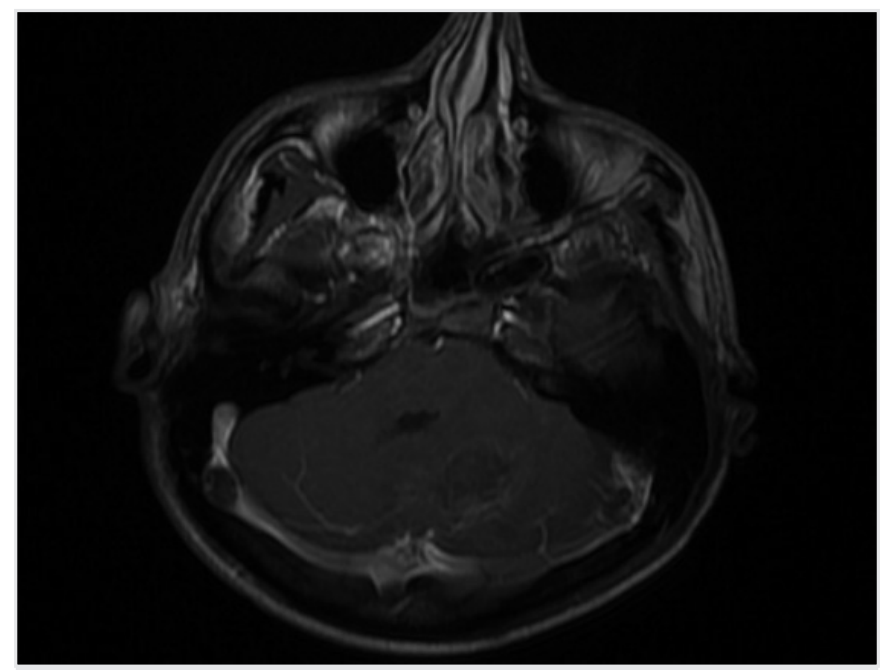

Figure 2. Axial contrast-enhanced T1W images showing a ring-enhancing lesion in the cerebellum

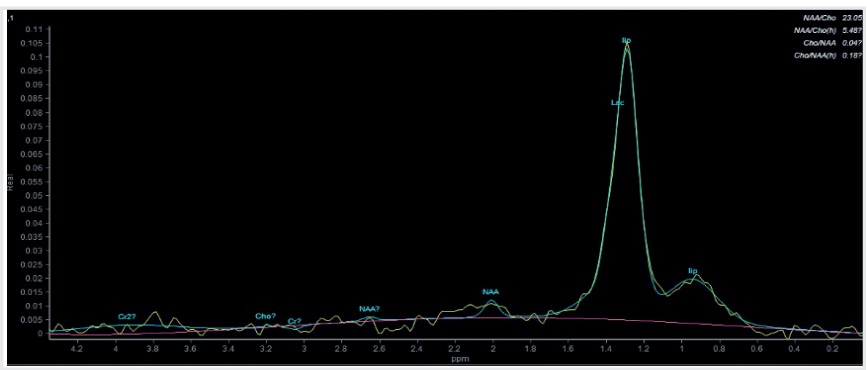

Figure 3. Magnetic Resonance Spectroscopy (single voxel, PRESS; TR/TE/ $\mathrm{NEX}=2000 \mathrm{~ms} / 32 \mathrm{~ms} / 128)$; reduced choline (3.19 ppm), creatinine (3.04 $\mathrm{ppm})$ and $\mathrm{N}$-acetyl aspartate $(2.00 \mathrm{ppm})$, increased lipid-lactate peak (1.33 ppm)

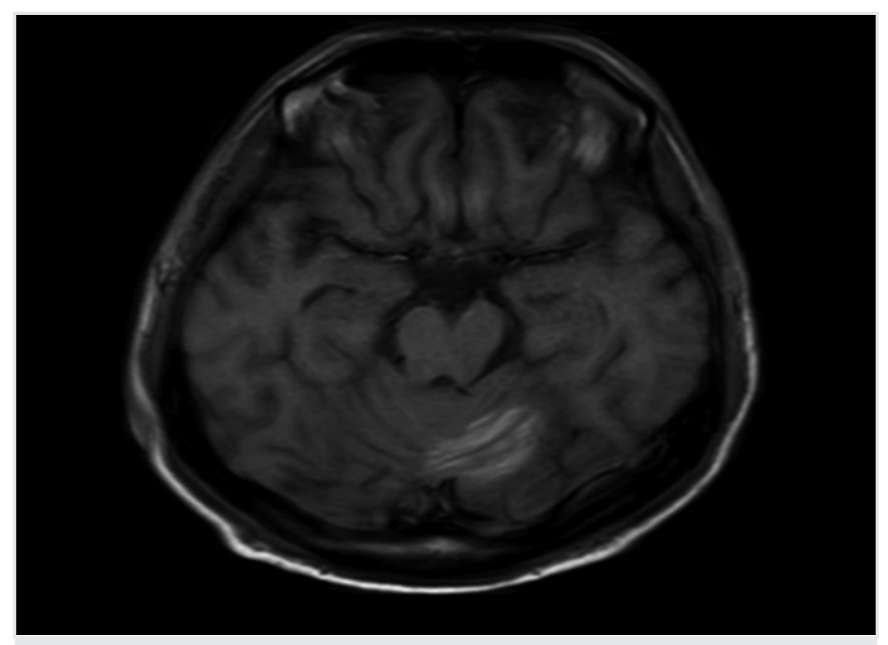

Figure 4a. Axial T1W image showing hemorrhagic transformation developed in the cerebellum 


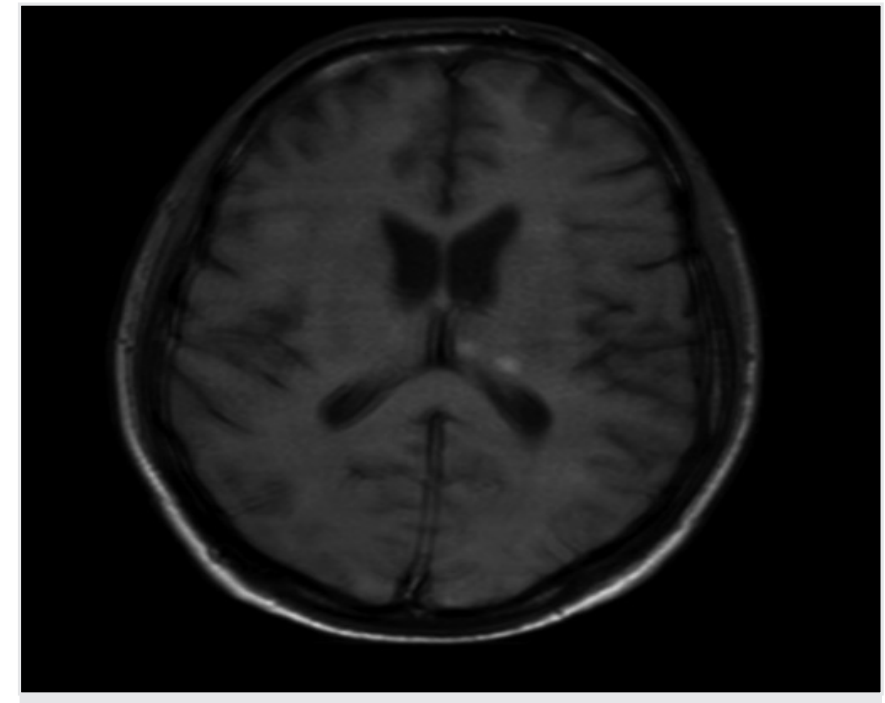

Figure 4b. Axial T1W image showing hemorrhagic transformation developed in the basal ganglia

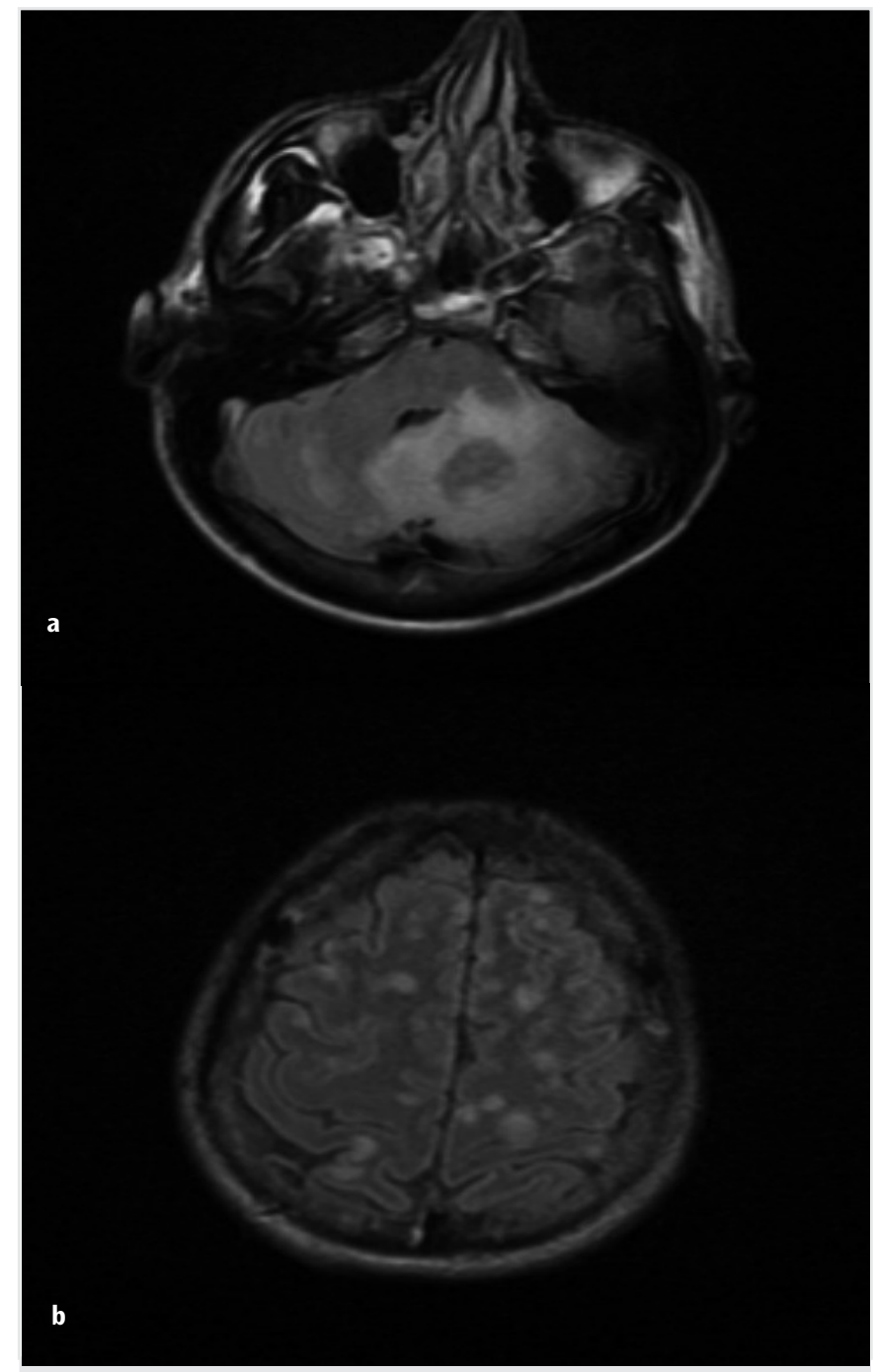

Figure 5a,b. Axial T2-FLAIR image of the patient on admission

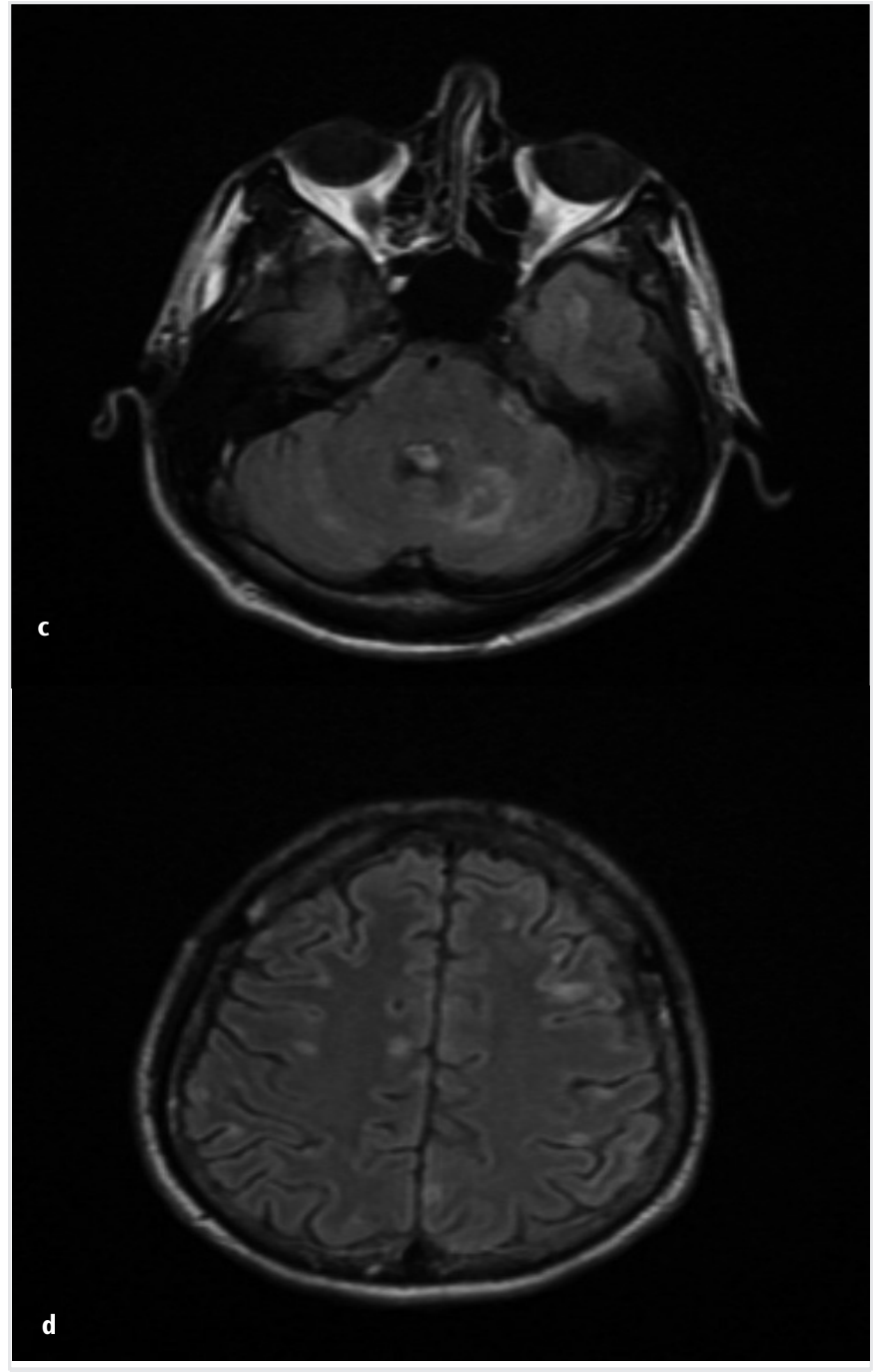

Figure $5 c, d$. Axial T2-FLAIR image of the patient during treatment period

In our patient, MRS demonstrated Lip/Lac peaks compared to healthy brain parenchyma (Figure 3). Brain biopsy could not be performed. Neurotoxoplasmosis was suspected with clinical and MRI findings. Antiviral, antiparasitic and anti-edema treatment was initiated. In control MRI, T1W hyperintense, T2W hypointense areas compatible with early subacute hemorrhage developed in some lesions (Figure 4). The patient had no history of thrombocytopenia, hemorrhagic diathesis and trauma. In the second control brain MRI, the number and size of the lesions decreased and the clinical improvement was observed during this period (Figure 5). In this case report, consent was obtained from the patient to present the case.

\section{Discussion}

Neurotoxoplasmosis is an important diagnosis in HIV-positive patients. Neurotoxoplasmosis in patients with AIDS is due to the reactivation of acquired infection as immunity decreases when CD4 count is less than $200 / \mu \mathrm{L}(5)$. In patients with suspected neurotoxoplasmosis, it is necessary to define bradyzoites in brain tissue and to determine toxoplasma gondii DNA in the cerebrospinal fluid with polymerase chain reaction 
test to confirm the diagnosis. However, in patients with suspected neurotoxoplasmosis, treatment precedes the diagnosis and brain MRI and MRS provide valuable information for toxoplasma encephalitis (6). In brain MRI, multiple ring enhancing lesions with edema and mass effect at the corticomedullary junction of frontal and parietal lobe, centrum semiovale and basal ganglia in patients with AIDS are diagnostic for neurotoxoplasmosis. Ring enhancing lesions in brain MRI can be seen in abscess, glioblastoma, tuberculoma, metastasis and radiation necrosis $(7,8)$. The eccentric target sign is considered pathognomonic for neurotoxoplasmosis (9). In MRS, neurotoxoplasmosis is generally associated with an increase in Cho and decreases in NAA along with the presence of lactate-lipid peaks. Gupta et al. (10) reported that MRS could provide information about definitive diagnosis, especially in brain abscess and parasitic infection, when combined with diagnostic imaging. Follow-up MRI should be used for the evaluation of response to medical treatment. In our case, we detected hemorrhagic transformation in follow-up MRI.

\section{Conclusion}

We report MRI and MRS findings of neurotoxoplasmosis in an HIVpositive patient. When neurotoxoplasmosis is suspected in a patient with AIDS with ring enhancing lesions with edema in brain MRI, medical treatment should be performed at the earliest. The presence of lactate and lipid peak in MRS in addition to brain MRI supports the diagnosis of neurotoxoplasmosis in suspected patients with AIDS.

Informed Consent: Informed consent was obtained from the patient to present the case.

Peer-review: Externally peer-reviewed.

Author Contributions: Concept - P.G.C..; Design - P.G.Ç.; Supervision P.G.C.; Resources - P.G.C., S.S.K.; Materials - P.G.C., S.S.K.; Data Collection and/or Processing - P.G.C.., S.S.K.; Analysis and/ or Interpretation - P.G.C.., S.S.K.; Literature Search - P.G.C.; Writing Manuscript - P.G.C.; Critical Review - P.G.C., S.S.K.

Conflict of Interest: No conflict of interest was declared by the authors.

Financial Disclosure: The authors declared that this study received no financial support.

\section{References}

1. Kurne A, Ozkaya G, Karlioguz K, Shorbagi A, Ustaçelebi S, Karabudak R, et al. The colorful clinical spectrum of cerebral toxoplasmosis in five HIV positive cases: what comes out of Pandora's box? Mikrobiyol Bul 2006; 40: 85-92.

2. Montoya JG, Liesenfeld O. Toxoplasmosis. Lancet 2004; 363: 1965-76.

3. Naqi R, Azeemuddin M, Ahsan H. Cerebral toxoplasmosis in a patient with acquired immunodeficiency syndrome. J Pak Med Assoc 2010; 60: 316-8.

4. Porter SB, Sande MA. Toxoplasmosis of the central nervous system in the acquired immunodeficiency syndrome. N Engl J Med 1992; 327: 1643-8.

5. Berry. Diagnostic Radiology : Neuroradiology: Head and neck imaging. Jaypee Brothers Medical Publishers (P) Ltd. ISBN:8180616363.

6. Ramsey RG, Gean AD. Neuroimaging of AIDS. I. Central nervous system toxoplasmosis. Neuroimaging Clin N Am 1997; 7: 171-86.

7. Garg RK, Sinha MK. Multiple ring-enhancing lesions of the brain. J Postgrad Med 2010; 56: 307-16

8. James J, Thulaseedharan NK. Ring enhancing lesions in the brain of an HIV infected patient: A diagnostic challenge. Pan Afr Med J 2017; 26: 185.

9. Kumar GG, Mahadevan A, Guruprasad AS, Kovoor JM, Satishchandra P, Nath A, et al. Eccentric target sign in cerebral toxoplasmosis: neuropathological correlate to the imaging feature. J Magn Reson Imaging 2010; 31: 1469-72.

10. Gupta RK, Jobanputra KJ, Yadav A. MR spectroscopy in brain infections. Neuroimaging Clin N Am 2013; 23: 475-98. 